\title{
GAMBARAN TINGKAT STRESS KERJA ANTAR SHIFT KERJA PADA PETUGAS PENGUMPUL TOL SURABAYA
}

\author{
Ayyuda Asyraf Zahra, Sho'im Hidayat \\ Departemen Keselamatan dan Kesehatan Kerja \\ Fakultas Kesehatan Masyarakat Universitas Airlangga \\ E-mail: ayyuda22@gmail.com
}

\begin{abstract}
PT. (X), Surabaya is one of company that manages toll road or highway that implement the shift system of work. Shift work has the potential for job stress and other health problems. The purpose of this research was to identify descriptive the level of job stress between shift work at the toll collector in PT. (X), Surabaya. This research was an observational analytic study with cross sectional approach. 36 toll collector who work when the morning shift, afternoon, and evening at the toll gate $x$, toll gate $y$ and toll gate $z$ were chosen as sample by using Proportional Random Sampling method. The results showed when the shift I (morning) there were 15 respondents (41.7\%) suffered mild job stress and 21 respondents (58.3\%) suffered moderate job stress. At the shift II (evening) there were 12 respondents (33.3\%) suffered mild stress of work and 24 respondents (66.7\%) suffered moderate job stress, while at the shift III (evening) were 9 respondents (25\%) suffered light work stress and 27 respondents (75\%) suffered moderate job stress. Based on the research results, it can be concluded the level of job stress between of shift work on the toll collectors suffered mild and moderate stress. The greatest frequency of respondents suffered moderate job stress. Recommendation for the company is review the system of career development and maintaining training activities, while for workers is use the time to rest and regular exercise.
\end{abstract}

Keywords: job stress, shift work, toll collector

\begin{abstract}
ABSTRAK
PT. (X), Surabaya merupakan salah satu perusahaan sebagai penyelenggara jalan tol atau jalan bebas hambatan yang menerapkan sistem shift kerja. Shift kerja memiliki potensi untuk terjadinya stress kerja dan gangguan kesehatan lainnya. Tujuan dari penelitian ini adalah mengidentifikasi gambaran tingkat stress kerja antar shift kerja pada petugas pengumpul tol di PT. (X), Surabaya. Penelitian ini merupakan penelitian observasional analitik dengan pendekatan cross sectional. Sampel penelitian sebanyak 36 petugas pengumpul tol yang bekerja saat shift pagi, sore, dan malam pada gerbang tol $\mathrm{x}$, gerbang tol $\mathrm{y}$, dan gerbang tol $\mathrm{z}$ dengan menggunakan metode Proportional Random Sampling. Hasil penelitian menunjukkan pada saat shift I (pagi) terdapat 15 responden (41,7\%) mengalami stress kerja ringan dan 21 responden $(58,3 \%)$ mengalami stress kerja sedang. Pada saat shift II (sore) terdapat 12 responden (33,3\%) mengalami stress kerja ringan dan 24 responden $(66,7 \%)$ mengalami stress kerja sedang, sedangkan pada saat shift III (malam) sebanyak 9 responden (25\%) mengalami stress kerja ringan dan 27 responden (75\%) mengalami stress kerja sedang. Berdasarkan hasil penelitian, dapat disimpulkan tingkat stress kerja antar shift kerja pada petugas pengumpul tol mengalami stress kerja ringan dan sedang. Frekuensi terbesar responden mengalami stress kerja sedang. Saran untuk perusahaan adalah mengkaji ulang sistem pengembangan karir dan mempertahankan kegiatan training, sedangkan untuk pekerja dengan memanfaatkan waktu istirahat dan rutin berolahraga.
\end{abstract}

Kata kunci: stress kerja, shift kerja, pengumpul tol

\section{PENDAHULUAN}

Perkembangan transportasi yang berkembang pesat berdampak pada kepadatan lalu lintas, salah satunya di Kota Surabaya. Jalan tol sebagai jalan bebas hambatan menjadi pilihan alternatif bagi kendaraan roda empat dan kendaraan berat untuk menghindari kemacetan di jalan umum dan mempercepat waktu tempuh perjalanan.

Menurut Dinas Infokom Jatim (2009), menyebutkan jumlah lalu lintas di jalan tol mencapai angka 56.300.000 dan diperkirakan akan mengalami peningkatan sekitar 3-4\%.

Data menunjukkan pada tahun 2013, volume lalu lintas rata-rata harian di jalan tol SurabayaGempol mencapai angka 223.209 dan terus meningkat pada tahun 2014 mencapai angka 226.454 (Jasamarga, 2015).

Hal tersebut menuntut perusahaan di bidang jasa pelayanan jalan bebas hambatan untuk meningkatkan produktivitasnya dengan aktif bekerja 
selama 24 jam per hari secara terus menerus dengan memberlakukan adanya sistem shift kerja.

Shift kerja merupakan suatu pola pengaturan waktu kerja dari perusahaan bagi tenaga kerja untuk melaksanakan tugas dan tanggung jawab yang diberikan, pembagian waktu biasanya dibagi menjadi tiga yaitu pagi, sore, dan malam (Suma'mur, 1994).

Menurut Munandar (2001), Shift kerja termasuk tuntutan tugas yang merupakan faktor instrinsik pekerjaan yang dapat menjadi salah satu sumber terjadinya stress kerja.

Stress merupakan ketidaksesuaian antara individu baik kepribadian, bakat, kemampuan dengan lingkungannya sehingga tidak mampu menghadapi berbagai tuntutan (Munandar, 2001).

Stress kerja adalah suatu bentuk reaksi fisik dan emosional yang terjadi karena ketidaksesuaian pekerjaan dengan kemampuan pekerja, sumber daya, atau kebutuhan pekerja (NIOSH, 2000).

Stress kerja dapat terjadi karena adanya faktorfaktor yang menjadi pemicu diantaranya adalah hubungan dengan rekan kerja, hubungan dengan atasan, pengembangan karir. Tingkat stress bagi tiap individu juga berbeda tergantung dari karakteristik individu.

Stress kerja dapat berdampak positif dan negatif bagi individu tergantung bagaimana individu meresponnya. Stress kerja berdampak positif bagi individu karena adanya stress memacu seseorang untuk bekerja dan menyelesaikan tugas dengan baik sehingga stress bersifat membangun atau yang disebut dengan eustres. Stress kerja berdampak negatif ketika seseorang tidak mampu untuk mengatasinya sehingga bersifat merusak atau disebut dengan distress, serta berakibat pada penurunan kinerja, tingkat absensi tinggi, munculnya penyakit dan sebagainya (Walker, 2002).

Stress kerja juga berdampak pada perusahaan atau organisasi, salah satunya menyebabkan kerugian finansial yang jumlahnya tidak sedikit (Saragih, 2010).

Bekerja baik pada pagi, sore, ataupun malam hari memiliki risiko yang berbeda. Pada saat pagi seseorang akan bekerja normal sesuai fungsi tubuhnya, sedangkan pada sore ataupun malam hari jam normal seseorang untuk beristirahat namun tetap digunakan untuk bekerja.

Menurut Munandar (2001), bekerja pada saat malam hari memiliki risiko mengalami tingkat stress kerja lebih tinggi daripada bekerja pada saat pagi ataupun sore hari dan merupakan sumber utama stress bagi para pekerja pabrik.
Bekerja pada malam hari juga akan menimbulkan masalah lain diantaranya, munculnya gangguan tidur dan pencernaan, kemampuan kerja berkurang, kesalahan dan kecelakaan kerja meningkat, serta mengganggu hubungan sosial dan keluarga (Winarsunu, 2008).

PT. (X), Surabaya merupakan salah satu perusahaan penyelenggara jalan tol atau yang bergerak dibidang jasa pelayanan jalan bebas hambatan.

PT. (X), Surabaya menerapkan sistem shift kerja yaitu dalam satu hari terdapat tiga shift dan setiap shift bekerja selama 8 jam seperti pukul 06.00-14.00 WIB.

Hasil wawancara dengan beberapa petugas pengumpul tol di PT. (X), Surabaya banyak ditemui beberapa keluhan dan hambatan dalam pekerjaannya. Mereka juga merasakan seperti sakit kepala, jenuh, mudah lelah, dan keluhan lain yang menandakan gejala dari timbulnya stress.

Pekerjaan sebagai pengumpul tol yang melayani transaksi terbuka, membutuhkan ketelitian dalam hal pembayaran dan pengembalian uang pengguna jalan tol serta tanggung jawab hasil kerja transaksi tol berupa uang pendapatan tol dan hasil kerja lainnya yang diberikan kepada atasan. Selain itu bekerja pada ruangan terbatas dalam gardu tol serta jenis pekerjaan monoton yang menimbulkan rutinitas kerja dan juga memungkinkan terjadinya stress kerja.

Tujuan dari penelitian ini adalah mengidentifikasi gambaran tingkat stress kerja antar shift kerja pada petugas pengumpul tol di PT. (X), Surabaya.

\section{METODE}

Metode penelitian yang digunakan adalah penelitian observasional analitik. Bila ditinjau dari desain studinya, penelitian ini termasuk cross sectional di mana penelitian dilakukan serentak pada satu waktu tertentu.

Populasi dalam penelitian ini adalah seluruh petugas pengumpul tol pada gerbang tol $\mathrm{x}$, gerbang tol y, dan gerbang tol z di PT. (X), Surabaya yang menjalani ketiga shift kerja pagi, sore, dan malam yang berjumlah 66 orang.

Penentuan sampel menggunakan kriteria inklusi dan ekslusi. Adapun kriteria inklusi yang digunakan dalam penelitian ini antara lain: berjenis kelamin laki-laki, bekerja dengan ketiga shift yang ada, dan bersedia berpartisipasi dalam penelitian dengan 
menandatangani lembar persetujuan tertulis. Kriteria ekslusi sebagai berikut: menolak menjadi responden dan berhalangan hadir atau tidak berada di tempat penelitian pada waktu pelaksanaan penelitian sesuai dengan shift kerjanya.

Perhitungan besar sampel menggunakan teknik Simple Random Sampling didapatkan besar sampel sebanyak 36 orang, dan menggunakan rumus Proportional Random Sampling untuk menentukan jumlah sampel dari setiap kelompok berdasarkan proporsi (Nazir, 1998) didapatkan 9 orang dari gerbang tol $\mathrm{x}, 14$ orang dari gerbang tol $\mathrm{y}$, dan 13 orang dari gerbang tol $\mathrm{z}$.

Variabel independen yang diteliti adalah shift kerja, karakteristik responden (umur, masa kerja, status perkawinan, dan tipe kepribadian), hubungan dengan rekan kerja, hubungan dengan atasan, dan sistem pengembangan karir. Sedangkan variabel dependen yang diteliti adalah tingkat stress kerja.

Pengumpulan data dilakukan dengan wawancara menggunakan lembar kueisoner tipe kepribadian yang dikembangkan oleh Friedman dan Ulmer (1984) dalam bukunya "Treating Type A Behavior - And Your Heart", dan kueisoner OSI-R $R^{T M}$ (Occupational Stress Inventory-Revised Edition) dari Osipow dan Spokane (1998) yang telah dimodifikasi oleh Novianita (dalam Martina, 2012). Kuesioner ini telah diuji validitas dan reabilitasnya dengan skor total item minimum $r=0,2$. Tingkat stress kerja kemudian dikategorikan menjadi tiga yaitu stress ringan (25-58), stress sedang (59-92), dan stress tinggi (93-125).

Pembagian kuesioner dilakukan secara bertahap sebanyak 3 kali pada masing-masing shift kerja dengan selang waktu pembagian sesuai jadwal shift kerja responden.

Data yang diperoleh kemudian dianalisis secara deskriptif dengan penyajian tabel distribusi frekuensi dalam bentuk angka mutlak dan presentase.

\section{HASIL}

Berdasarkan Tabel 1. Hubungan dengan rekan kerja antar shift kerja yaitu shift I (pagi), shift II (sore), dan shift III (malam) dapat diketahui dari 36 responden (100\%) yang bekerja saat shift I (pagi) dan shift II (sore) terdapat 31 responden $(86,1 \%)$ mengatakan hubungan dengan rekan kerja baik dan 5 responden (13,9\%) mengatakan hubungan dengan rekan kerja tidak baik dan yang melaksanakan shift III (malam) terdapat 28 responden $(77,8 \%)$ mengatakan hubungan dengan rekan kerja baik dan 8 responden $(22,2 \%)$ mengatakan hubungan dengan rekan kerja tidak baik.

Hubungan dengan atasan antar shift kerja yaitu shift I (pagi), shift II (sore), dan shift III (malam) berdasarkan Tabel 1. dapat diketahui dari 36 responden $(100 \%)$ yang bekerja saat shift I (pagi) terdapat 32 responden $(88,9 \%)$ mengatakan hubungan dengan atasan baik dan 4 responden $(11,1 \%)$ mengatakan hubungan dengan atasan tidak baik. Pada saat melaksanakan shift II (sore) terdapat 31 responden $(86,1 \%)$ mengatakan hubungan dengan atasan baik dan 5 responden (13,9\%) mengatakan hubungan dengan atasan tidak baik, sedangkan pada saat melaksanakan shift III (malam) sebanyak 29 responden $(80,6 \%)$ mengatakan hubungan dengan atasan baik dan 7 responden $(19,4 \%)$ mengatakan hubungan dengan atasan tidak baik.

Dapat disimpulkan hubungan dengan rekan kerja dan hubungan dengan atasan baik pada ketiga shift kerja yaitu shift I (pagi), shift II (sore), dan shift III (malam) sebagian besar responden mengatakan baik.

Jika dilihat antar shift kerja, shift I (pagi), shift II (sore), dan shift III (malam) terjadi penurunan frekuensi responden yang mengatakan hubungan dengan rekan kerja dan hubungan dengan atasan baik, sebaliknya responden yang mengatakan

Tabel 1. Hubungan dengan Rekan Kerja dan Atasan Antar Shift Kerja

\begin{tabular}{lrrrrrr}
\hline \multirow{2}{*}{ Variabel } & \multicolumn{2}{c}{ Shift I (Pagi) } & \multicolumn{2}{c}{ Shift II (Sore) } & \multicolumn{2}{c}{ Shift III (Malam) } \\
\cline { 2 - 7 } & $\mathbf{n}$ & $\mathbf{\%}$ & $\mathbf{n}$ & $\mathbf{\%}$ & $\mathbf{n}$ & $\mathbf{\%}$ \\
\hline Hubungan dengan Rekan Kerja & & & & & & \\
$\quad$ Baik & 31 & 86,1 & 31 & 86,1 & 28 & 77,8 \\
$\quad$ Tidak Baik & 5 & 13,9 & 5 & 13,9 & 8 & 22,2 \\
Hubungan dengan Atasan & & & & & & \\
$\quad$ Baik & 32 & 88,9 & 31 & 86,1 & 29 & 80,6 \\
$\quad$ Tidak Baik & 4 & 11,1 & 5 & 13,9 & 7 & 19,4 \\
\hline Total & $\mathbf{3 6}$ & $\mathbf{1 0 0}$ & $\mathbf{3 6}$ & $\mathbf{1 0 0}$ & $\mathbf{3 6}$ & $\mathbf{1 0 0}$ \\
\hline
\end{tabular}


hubungan dengan rekan kerja dan hubungan dengan atasan tidak baik mengalami peningkatan. Penurunan dan peningkatan tersebut terjadi pada shift III (malam).

Tabel 2. Sistem Pengembangan Karir

\begin{tabular}{lcc}
\hline \multicolumn{1}{c}{$\begin{array}{c}\text { Sistem } \\
\text { Pengembangan Karir }\end{array}$} & \multicolumn{2}{c}{ Frekuensi } \\
\cline { 2 - 3 } \multicolumn{1}{c}{ Baik } & n & \% \\
Buruk & 15 & 41,7 \\
Total & 21 & 58,3 \\
\hline
\end{tabular}

Dari Tabel 2 dapat diketahui sistem pengembangan karir. Hasil penelitian menunjukkan bahwa sebagian besar responden dari 36 responden $(100 \%)$ mengatakan sistem pengembangan karir buruk sebanyak 21 responden $(58,3 \%)$ dan sebanyak 15 responden $(41,7 \%)$ mengatakan sistem pengembangan karir baik.

Sebagian besar responden dari 36 responden $(100 \%)$ tergolong dalam kelompok umur 41 sampai dengan 60 tahun sebanyak 26 responden $(72,2 \%)$, memiliki masa kerja lebih dari 10 tahun sebanyak 25 responden $(69,4 \%)$, memiliki status perkawinan menikah sebanyak 28 responden $(77,8 \%)$, dan memiliki tipe kepribadian B sebanyak 34 responden $(94,4 \%)$.

Berdasarkan Tabel 3 dapat diketahui tingkat stress kerja pada saat shift I (pagi) menurut karakteristik individu yaitu umur, masa kerja, status perkawinan, dan tipe kepribadian. Tingkat stress kerja pada saat shift I (pagi) yaitu mengalami stress kerja ringan dan stress kerja sedang.

Menurut umur, pada kelompok umur 18 sampai dengan 40 tahun dari 10 responden (100\%) terdapat
4 responden (40\%) yang mengalami tingkat stress kerja ringan dan 6 responden $(60 \%)$ yang mengalami stress kerja sedang. Pada kelompok umur 41 sampai dengan 60 tahun dari 26 responden $(100 \%)$ terdapat 11 responden $(42,3 \%)$ yang mengalami stress kerja ringan dan 15 responden $(57,7 \%)$ yang mengalami stress kerja sedang.

Masa kerja menurut Siboro (2008) dikelompokkan menjadi tiga yaitu kurang dari 5 tahun, 5 sampai dengan 10 tahun, dan lebih dari 10 tahun. Pada kelompok masa kerja kurang dari 5 tahun dari 11 responden $(100 \%)$ terdapat 4 responden $(36,4 \%)$ yang mengalami stress kerja ringan dan 7 responden $(63,6 \%)$ yang mengalami stress kerja sedang. Pada kelompok masa kerja 5 sampai dengan 10 tahun tidak terdapat responden yang masuk dalam kelompok tersebut. Pada kelompok masa kerja lebih dari 10 tahun dari 25 responden $(100 \%)$ terdapat 11 responden (44\%) yang mengalami stress kerja ringan dan 14 responden (56\%) yang mengalami stress kerja sedang.

Menurut status perkawinan, pada status perkawinan menikah dari 28 responden $(100 \%)$ terdapat 11 responden $(39,3 \%)$ yang mengalami stress kerja ringan dan 17 responden $(60,7 \%)$ yang mengalami stress kerja sedang. Pada status perkawinan belum menikah dari 8 responden $(100 \%)$ terdapat 4 responden $(50 \%)$ yang mengalami stress kerja ringan dan stress kerja sedang.

Menurut tipe kepribadian, tipe kepribadian A dari 2 responden (100\%) keseluruhan mengalami stress kerja sedang, sedangkan pada tipe kepribadian B dari 34 responden $(100 \%)$ terdapat 15 responden $(44,1 \%)$ yang mengalami stress kerja ringan dan 19 responden $(55,9 \%)$ yang mengalami stress kerja sedang.

Tabel 3. Tingkat Stress Kerja Menurut Karakteristik Responden pada Saat Shift I (Pagi)

\begin{tabular}{|c|c|c|c|c|c|c|}
\hline \multirow{3}{*}{ Item } & \multicolumn{4}{|c|}{ Tingkat Stress Kerja } & \multirow{2}{*}{\multicolumn{2}{|c|}{ Total }} \\
\hline & \multicolumn{2}{|c|}{ Ringan } & \multicolumn{2}{|c|}{ Sedang } & & \\
\hline & $\mathbf{n}$ & $\%$ & $\mathbf{n}$ & $\%$ & $\mathbf{n}$ & $\%$ \\
\hline \multicolumn{7}{|l|}{ Umur } \\
\hline $18-40$ tahun & 4 & 40 & 6 & 60 & 10 & 100 \\
\hline 41-60 tahun & 11 & 42,3 & 15 & 57,7 & 26 & 100 \\
\hline \multicolumn{7}{|l|}{ Masa Kerja } \\
\hline$<5$ tahun & 4 & 36,4 & 7 & 63,6 & 11 & 100 \\
\hline$>10$ tahun & 11 & 44 & 14 & 56 & 25 & 100 \\
\hline \multicolumn{7}{|l|}{ Status Perkawinan } \\
\hline Menikah & 11 & 39,3 & 17 & 60,7 & 28 & 100 \\
\hline Belum Menikah & 4 & 50 & 4 & 50 & 8 & 100 \\
\hline \multicolumn{7}{|l|}{ Tipe Kepribadian } \\
\hline A & 0 & 0 & 2 & 100 & 2 & 100 \\
\hline B & 15 & 44,1 & 19 & 55,9 & 34 & 100 \\
\hline
\end{tabular}


Tabel 4. Tingkat Stress Kerja Menurut Karakteristik Responden pada Saat Shift II (Sore)

\begin{tabular}{|c|c|c|c|c|c|c|}
\hline \multirow{3}{*}{ Item } & \multicolumn{4}{|c|}{ Tingkat Stress Kerja } & \multirow{2}{*}{\multicolumn{2}{|c|}{ Total }} \\
\hline & \multicolumn{2}{|c|}{ Ringan } & \multicolumn{2}{|c|}{ Sedang } & & \\
\hline & $\mathbf{n}$ & $\%$ & $\mathbf{n}$ & $\%$ & $\mathrm{n}$ & $\%$ \\
\hline \multicolumn{7}{|l|}{ Umur } \\
\hline $18-40$ tahun & 4 & 40 & 6 & 60 & 10 & 100 \\
\hline $41-60$ tahun & 8 & 30,8 & 18 & 69,2 & 26 & 100 \\
\hline \multicolumn{7}{|l|}{ Masa Kerja } \\
\hline$<5$ tahun & 4 & 36,4 & 7 & 63,6 & 11 & 100 \\
\hline$>10$ tahun & 8 & 32 & 17 & 68 & 25 & 100 \\
\hline \multicolumn{7}{|l|}{ Status Perkawinan } \\
\hline Menikah & 9 & 32,1 & 19 & 67,9 & 28 & 100 \\
\hline Belum Menikah & 3 & 37,5 & 5 & 62,5 & 8 & 100 \\
\hline \multicolumn{7}{|l|}{ Tipe Kepribadian } \\
\hline A & 0 & 0 & 2 & 100 & 2 & 100 \\
\hline B & 12 & 35,3 & 22 & 64,7 & 34 & 100 \\
\hline
\end{tabular}

Berdasarkan Tabel 4 dapat diketahui tingkat stress kerja pada saat shift II (sore) menurut karakteristik individu yaitu umur, masa kerja, status perkawinan, dan tipe kepribadian.

Sebagian besar responden dari 36 responden $(100 \%)$ termasuk dalam kelompok umur 41 sampai dengan 60 tahun, memiliki masa kerja lebih dari 10 tahun, memiliki status perkawinan menikah, dan memiliki tipe kepribadian B.

Hasil penelitian menunjukkan tingkat stress kerja pada saat shift II (sore) yaitu mengalami stress kerja ringan dan stress kerja sedang.

Menurut umur, pada kelompok umur 18 sampai dengan 40 tahun dari 10 responden (100\%) terdapat 4 responden (40\%) yang mengalami tingkat stress kerja ringan dan 6 responden $(60 \%)$ yang mengalami stress kerja sedang. Pada kelompok umur 41 sampai dengan 60 tahun dari 26 responden (100\%) terdapat 8 responden $(30,8 \%)$ yang mengalami stress kerja ringan dan 18 responden $(69,2 \%)$ yang mengalami stress kerja sedang.

Masa kerja dikelompokkan menjadi tiga yaitu kurang dari 5 tahun, 5 sampai dengan 10 tahun, dan lebih dari 10 tahun Siboro (2008). Pada kelompok masa kerja kurang dari 5 tahun dari 11 responden $(100 \%)$ terdapat 4 responden $(36,4 \%)$ yang mengalami stress kerja ringan dan 7 responden (63,6\%) yang mengalami stress kerja sedang. Pada kelompok masa kerja 5 sampai dengan 10 tahun tidak terdapat responden yang masuk dalam kelompok tersebut. Pada kelompok masa kerja lebih dari 10 tahun dari 25 responden $(100 \%)$ terdapat 8 responden $(32 \%)$ yang mengalami stress kerja ringan dan 17 responden (68\%) yang mengalami stress kerja sedang.
Menurut status perkawinan, pada status perkawinan menikah dari 28 responden $(100 \%)$ terdapat 9 responden $(32,1 \%)$ yang mengalami stress kerja ringan dan 19 responden $(67,9 \%)$ yang mengalami stress kerja sedang. Pada status perkawinan belum menikah dari 8 responden $(100 \%)$ terdapat 3 responden $(37,5 \%)$ yang mengalami stress kerja ringan dan 5 responden $(62,5 \%)$ yang mengalami stress kerja sedang.

Tipe kepribadian digolongkan menjadi tipe kepribadian A dan tipe kepribadian B. Tipe kepribadian A dari 2 responden (100\%) keseluruhan mengalami stress kerja sedang, sedangkan pada tipe kepribadian B dari 34 responden (100\%) terdapat 12 responden $(35,3 \%)$ yang mengalami stress kerja ringan dan 22 responden $(64,7 \%)$ yang mengalami stress kerja sedang.

Berdasarkan Tabel 5 dapat diketahui tingkat stress kerja pada saat shift III (malam) menurut karakteristik individu yaitu umur, masa kerja, status perkawinan, dan tipe kepribadian.

Sebagian besar responden dari 36 responden $(100 \%)$ termasuk dalam kelompok umur 41 sampai dengan 60 tahun, memiliki masa kerja lebih dari 10 tahun, memiliki status perkawinan menikah, dan memiliki tipe kepribadian B.

Hasil penelitian menunjukkan tingkat stress kerja pada saat shift III (malam) yaitu mengalami stress kerja ringan dan stress kerja sedang.

Menurut kelompok umur 18 sampai dengan 40 tahun dari 10 responden $(100 \%)$ terdapat 2 responden $(20 \%)$ yang mengalami tingkat stress kerja ringan dan 8 responden (80\%) yang mengalami stress kerja sedang, sedangkan pada kelompok umur 41 sampai dengan 60 tahun dari 26 responden 
Tabel 5. Tingkat Stress Kerja Menurut Karakteristik Responden pada Saat Shift III (Malam)

\begin{tabular}{|c|c|c|c|c|c|c|}
\hline \multirow{3}{*}{ Item } & \multicolumn{4}{|c|}{ Tingkat Stress Kerja } & \multirow{2}{*}{\multicolumn{2}{|c|}{ Total }} \\
\hline & \multicolumn{2}{|c|}{ Ringan } & \multicolumn{2}{|c|}{ Sedang } & & \\
\hline & $\mathbf{n}$ & $\%$ & $\mathbf{n}$ & $\%$ & $\mathbf{n}$ & $\%$ \\
\hline \multicolumn{7}{|l|}{ Umur } \\
\hline $18-40$ tahun & 2 & 20 & 8 & 80 & 10 & 100 \\
\hline $41-60$ tahun & 7 & 26,9 & 19 & 73,1 & 26 & 100 \\
\hline \multicolumn{7}{|l|}{ Masa Kerja } \\
\hline$<5$ tahun & 2 & 18,2 & 9 & 81,8 & 11 & 100 \\
\hline$>10$ tahun & 7 & 28 & 18 & 72 & 25 & 100 \\
\hline \multicolumn{7}{|c|}{ Status Perkawinan } \\
\hline Menikah & 8 & 28,6 & 20 & 71,4 & 28 & 100 \\
\hline Belum Menikah & 1 & 12,5 & 7 & 87,5 & 8 & 100 \\
\hline \multicolumn{7}{|l|}{ Tipe Kepribadian } \\
\hline A & 0 & 0 & 2 & 100 & 2 & 100 \\
\hline B & 9 & 26,5 & 25 & 73,5 & 34 & 100 \\
\hline
\end{tabular}

$(100 \%)$ terdapat 7 responden $(26,9 \%)$ yang mengalami stress kerja ringan dan 19 responden (73,1\%) yang mengalami stress kerja sedang.

Menurut masa kerja, Siboro (2008) mengelompokkan menjadi tiga yaitu kurang dari 5 tahun, 5 sampai dengan 10 tahun, dan lebih dari 10 tahun. Pada kelompok masa kerja kurang dari 5 tahun dari 11 responden $(100 \%)$ terdapat 2 responden $(18,2 \%)$ yang mengalami stress kerja ringan dan 9 responden $(81,8 \%)$ yang mengalami stress kerja sedang, sedangkan pada kelompok masa kerja lebih dari 10 tahun dari 25 responden $(100 \%)$ terdapat 7 responden $(28 \%)$ yang mengalami stress kerja ringan dan 18 responden (72\%) yang mengalami stress kerja sedang. Pada kelompok masa kerja 5 sampai dengan 10 tahun tidak terdapat responden yang masuk dalam kelompok tersebut.

Status perkawinan adalah menikah dan belum menikah. Pada status perkawinan menikah dari 28 responden $(100 \%)$ terdapat 8 responden $(28,6 \%)$ yang mengalami stress kerja ringan dan 20 responden $(71,4 \%)$ yang mengalami stress kerja sedang, sedangkan pada status perkawinan belum menikah dari 8 responden $(100 \%)$ terdapat 1 responden $(12,5 \%)$ yang mengalami stress kerja ringan dan 7 responden $(87,5 \%)$ yang mengalami stress kerja sedang.

Menurut tipe kepribadian, tipe kepribadian A secara keseluruhan yaitu 2 responden $(100 \%)$ mengalami stress kerja sedang, sedangkan pada tipe kepribadian B dari 34 responden $(100 \%)$ terdapat 9 responden $(26,5 \%)$ yang mengalami stress kerja ringan dan 25 responden $(73,5 \%)$ yang mengalami stress kerja sedang.
Tabel 6. Tingkat Stress Kerja Antar Shift Kerja di PT. (X), Surabaya Mei 2015.

\begin{tabular}{lccccrr}
\hline $\begin{array}{c}\text { Tingkat } \\
\text { Stress }\end{array}$ Kerja & \multicolumn{2}{c}{$\begin{array}{c}\text { Shift I } \\
\text { (Pagi) }\end{array}$} & \multicolumn{2}{c}{$\begin{array}{c}\text { Shift II } \\
\text { (Sore) }\end{array}$} & \multicolumn{2}{c}{$\begin{array}{c}\text { Shift III } \\
\text { (Malam) }\end{array}$} \\
\cline { 2 - 7 } & $\mathbf{n}$ & $\mathbf{n}$ & $\mathbf{\%}$ & $\mathbf{n}$ & $\%$ \\
\hline Ringan & 15 & 41,7 & 12 & 33,3 & 9 & 25 \\
Sedang & 21 & 58,3 & 24 & 66,7 & 27 & 75 \\
\hline Total & $\mathbf{3 6}$ & $\mathbf{1 0 0}$ & $\mathbf{3 6}$ & $\mathbf{1 0 0}$ & $\mathbf{3 6}$ & $\mathbf{1 0 0}$ \\
\hline
\end{tabular}

Berdasarkan Tabel 6 dapat diketahui bahwa pada ketiga shift kerja, responden mengalami stress kerja ringan dan sedang.

Hasil penelitian dari 36 responden (100\%) yang bekerja saat shift I (pagi) terdapat 15 responden $(41,7 \%)$ mengalami stress kerja ringan dan 21 responden $(58,3 \%)$ mengalami stress kerja sedang. Pada saat melaksanakan shift II (sore) terdapat 12 responden $(33,3 \%)$ mengalami stress kerja ringan dan 24 responden $(66,7 \%)$ mengalami stress kerja sedang, sedangkan pada saat melaksanakan shift III (malam) sebanyak 9 responden (25\%) mengalami stress kerja ringan dan 27 responden (75\%) mengalami stress kerja sedang.

Sistem shift kerja yang diterapkan oleh PT. (X), Surabaya adalah sistem shift kerja yang dibagi menjadi 3 shift yaitu shift I (pagi), shift II (sore), dan shift III (malam).

Masing-masing shift bekerja selama 8 jam dan disediakan waktu istirahat selama 1 jam di mana waktu istirahat ditentukan oleh tiap gerbang tol yang disesuaikan dengan kepadatan arus lalu lintas, sehingga tiap gerbang tol memiliki waktu istirahat yang berbeda. Pada saat petugas pengumpul tol istirahat, akan ada petugas pengumpul tol lain 
yang stanby berjaga untuk menggantikan sehingga aktivitas gardu tol terus berjalan.

Pengaturan jadwal shift kerja menggunakan sistem 3-1-4-2 yaitu 3 hari kerja dengan 1 hari libur, dan 4 hari kerja dengan 2 hari libur, begitu seterusnya untuk pola perulangannya.

\section{PEMBAHASAN}

Hubungan dengan rekan kerja dan hubungan dengan atasan merupakan salah satu faktor terjadinya stress kerja.

Menurut Parasuraman, dkk (1992), bahwa dukungan sosial yang berasal dari atasan, teman sekerja, dan keluarga mempunyai peran yang besar untuk meringankan beban seseorang yang mengalami kelelahan fisik, emosional maupun mental.

Stress kerja merupakan salah satu contoh kelelahan emosinal maupun mental. Dukungan sosial dari atasan dan rekan kerja dapat terjalin ketika hubungan dengan rekan kerja dan hubungan dengan atasan baik.

Penelitian yang dilakukan oleh Britton dalam Andarika (2004), menyimpulkan bahwa dukungan sosial dari atasan berpengaruh positif terhadap kesehatan fisik dan kesehatan mental para karyawan.

Rekan kerja adalah teman di dalam melakukan pekerjaan atau seseorang yang selalu ada di sekeliling kita. Rekan kerja tidak hanya sekedar membantu pekerjaan kita melainkan rekan kerja bisa seperti sahabat dan teman yang menjadi pendengar serta memberikan saran kepada kita ketika ada masalah pekerjaan maupun masalah di rumah.

Begitu pula dengan atasan, atasan berperan sebagai seseorang yang mendukung atau memotivasi pekerjaan kita. Pada saat kita mendapat dukungan dan motivasi baik dari atasan maupun rekan kerja maka situasi lingkungan kerja akan baik akibatnya seseorang dapat bekerja lebih bersemangat dan meminimalkan terjadinya stress kerja.

Jika dilihat antar shift kerja, frekuensi responden yang mengatakan hubungan dengan rekan kerja dan hubungan dengan atasan baik mengalami penurunan, sebaliknya responden yang mengatakan hubungan dengan rekan kerja dan hubungan dengan atasan tidak baik mengalami peningkatan dan tertinggi pada saat melaksanakan shift III (malam).

Hal tersebut disebabkan oleh adanya kelelahan dan kondisi fisiologis sebagai akibat bioritmis tubuh. Saat bekerja malam hari seseorang akan lebih cepat merasakan kelelahan dan waktu yang seharusnya digunakan untuk beristirahat di rumah dan berkumpul bersama dengan keluarga serta berhubungan sosial dengan masyarakat tidak ada. Pada shift malam seseorang akan lebih kepikiran dengan apa yang terjadi di rumah dan ingin segera pulang ke rumah.

Pada umumnya fungsi tubuh akan meningkat pada pagi hari, mulai melemah pada siang hari dan menurun pada malam hari untuk pemulihan dan pembaharuan (Mc Cormick dan Ilgen, 1985).

Pada pagi hari seseorang akan lebih siap dan bersemangat serta lebih fresh untuk melakukan pekerjaan, sedangkan kondisi tersebut akan semakin menurun pada sore dan malam hari.

Hal itulah yang menyebabkan terjadi peningkatan frekuensi hubungan dengan rekan kerja dan hubungan dengan atasan di tempat kerja tidak baik, karena mereka merasakan kurang mendapat bantuan, dukungan dan perhatian serta tidak dapat menyampaikan keluhan yang dirasakan. Bagi tenaga kerja yang merasakan kurangnya mendapat dukungan sosial baik dari atasan maupun rekan kerja akan merasakan ketidakpuasan dalam pekerjaannya sehingga akan lebih mudah terkena stres.

Sistem pengembangan karir juga dapat memicu terjadinya stress kerja. Seseorang yang bekerja besar kemungkinan sejak awal bekerja telah memiliki harapan dalam pekerjaannya ke depan. Namun terkadang apa yang diharapkan tidak sesuai bahkan tidak tercapai, sehingga berdampak pada pekerjaan yang dilakukan.

Berdasarkan hasil wawancara, sebagian besar responden mengatakan sistem pengembangan karir yang buruk di mana pengembangan karir sulit untuk dilakukan.

Menurut Munandar (2001), promosi jabatan sendiri dapat menjadi pemicu terjadinya stress kerja bagi pekerja apabila tidak dipersiapkan untuk menerima pekerjaan yang dipromosikan, sehingga seseorang harus mempersiapkan diri jauh sebelum adanya promosi kerja untuk menerima jabatan baru.

Munandar (2001), juga menyatakan pengembangan karir merupakan pembangkit stress potensial yang mencakup ketidakpastian pekerjaan, promosi berlebih atau kurang, ketidakamanan dalam bekerja, ketakutan di keluarkan dari pekerjaan karena tidak ada lagi pekerjaan yang akan dilakukan, pensiun terlalu dini, frustasi terhadap apa yang telah dicapai oleh karir seseorang. 
Tingkat stress kerja antar shift kerja dapat berbeda tergantung dari karakteristik individu. Karakteristik individu yang diteliti adalah umur, masa kerja, status perkawinan, dan tipe kepribadian. Jenis kelamin dalam penelitian ini tidak diteliti tetapi dikendalikan dengan adanya kriteria inklusi dan ekslusi dikarenakan pada petugas pengumpul tol yang menjalani ketiga shift yaitu pagi, sore, dan malam adalah umumnya laki-laki.

Pada tingkat stress kerja menurut umur, Gunarsa (2008), mengelompokkan umur yang rentan terhadap stress menjadi dua kelompok yaitu masa dewasa muda (umur 21-40 tahun) dan masa dewasa madya (umur 40-60 tahun). Seseorang akan lebih rentan terhadap stress pada masa dewasa muda yaitu umur 21-40 tahun. Gunarsa (2008) juga menyebutkan pada usia 21-40 tahun seseorang akan mengalami pembentukan karir, pembinaan hubungan priawanita, memilih pasangan hidup, persaingan dalam pekerjaan, orientasi hidup, memikirkan pendidikan anak, dan pengunduran diri dari jabatan atau pekerjaan.

Hasil penelitian ini menunjukkan sebagian besar responden berumur 41-60 tahun yang termasuk ke dalam kategori dewasa muda (Hurlock, 2001).

Menurut Anoraga (1992), semakin bertambahnya umur seseorang atau semakin tua umur seseorang maka semakin kompleks masalah yang dihadapi sehingga semakin besar pula kemungkinan terjadinya stress. Hal tersebut juga sesuai dengan pernyataan Wildani (2012), bahwa seseorang yang memiliki umur tua sering muncul perasaan kehilangan minat, tidak partisipatif, bahkan ingin menyendiri sehingga menjadi pemicu terjadinya stress kerja.

Masa kerja adalah lama kerja responden terhitung sejak awal bekerja menjadi petugas pengumpul tol. Masa kerja merupakan salah satu pemicu terjadinya stress kerja.

Lama bekerja berhubungan dengan pengalaman seseorang dalam bekerja, semakin lama seseorang bekerja maka semakin banyak pengalaman yang didapatkan. Semakin banyak pengalaman dapat mengurangi stress kerja karyawan.

Robbins (2006), menyatakan bahwa seseorang yang bertahan lama dalam pekerjaannya akan semakin dapat menghadapi stress kerja dan memiliki strategi serta upaya untuk mengendalikan terjadinya stress kerja.

Hal tersebut bertolak belakang dengan pernyataan Siboro (2008), bahwa semakin lama masa kerja seseorang dapat menimbulkan kebosanan atau pekerjaan yang monoton dari tahun ke tahun dapat membuat seseorang bosan yang lama kelamaan akan mengalami stress yang secara langsung tidak disadari. Hal tersebut didukung oleh pernyataan Munandar (2001), bahwa masa kerja baru ataupun lama dapat memicu terjadinya stress kerja. Masa kerja dapat menimbulkan rutinitas dalam bekerja terutama rutinitas kerja yang selalu monoton sehingga muncul kebosanan dan disertai lingkungan kerja yang terbatas membuat pekerja menjadi jenuh yang pada akhirnya menimbulkan stress kerja bagi pekerja.

Status perkawinan dibedakan menjadi menikah dan belum menikah. Status perkawinan merupakan salah satu faktor terjadinya stress kerja.

Seseorang yang belum menikah cenderung berbeda dengan seseorang yang sudah menikah. Biasanya orang dengan status menikah cenderung memiliki stress kerja yang juga diakibatkan adanya masalah rumah tangga yang ikut di bawa saat bekerja.

Lama menikah seseorang juga berpengaruh terhadap masalah rumah tangga seseorang yang sudah menikah. Seseorang yang sudah lama menikah akan terbiasa dengan masalah yang muncul sehingga lebih mudah untuk mengatasinya bila dibandingkan dengan seseorang yang baru saja menikah yang masih belum memahami satu sama lain.

Selain itu tanggung jawab yang dimiliki seseorang yang sudah menikah lebih besar dari segi materi seiring dengan peningkatan kebutuhan hidup, pendidikan dan moral, dibanding dengan seseorang yang belum menikah. Terlebih jika memiliki jumlah anak banyak dan istri tidak bekerja hanya bekerja sebagai ibu rumah tangga menjadi tuntutan tersendiri. Hal ini didukung oleh pernyataan Santrock (2003), yang menyebutkan bahwa keluarga merupakan salah satu faktor penyebab terjadinya stress.

Pada tingkat stress kerja menurut tipe kepribadian, Friedman dan Roseman (1974), mengelompokkan tipe kepribadian individu menjadi dua tipe yaitu kepribadian A dan tipe kepribadian B. Pola perilaku yang ditunjukkan oleh tipe kepribadian A seperti (1) makan, berbicara, dan berjalan dengan cepat, (2) memiliki sifat ambisius, kompetitif, dan agresif. Pola perilaku dengan tipe kepribadian B seperti (1) makan, berjalan dan berbicara dengan lambat, (2) memiliki sifat lebih sabar, santai, dan tenang dibandingkan dengan tipe kepribadian $\mathrm{A}$.

Berdasarkan hasil penelitian menunjukkan responden dengan tipe kepribadian A keseluruhan 
mengalami stress kerja sedang, dan tidak ada satu pun yang mengalami stress kerja ringan, sedangkan responden dengan tipe kepribadian $\mathrm{B}$ cenderung lebih mengalami stress kerja ringan dan sedang.

Friedman \& Ulmer (1984), menjelaskan terdapat dua tipe kepribadian, tipe kepribadian A ternyata lebih rentan terhadap stress dibandingkan dengan tipe kepribadian B. Seseorang dengan tipe kepribadian A dianggap lebih memiliki kecenderungan untuk mengalami tingkat stress lebih tinggi, sebab mereka menempatkan diri mereka pada suatu tekanan waktu dan menciptakan suatu batas waktu tertentu untuk kehidupan mereka.

Berdasarkan hasil penelitian tingkat stress kerja antar shift kerja, dapat disimpulkan pada ketiga shift kerja responden mengalami stress kerja ringan dan sedang. Frekuensi terbesar responden mengalami stress kerja sedang pada ketiga shift kerja.

Tingginya persentase responden yang mengalami stress kerja sedang pada petugas pengumpul tol dipengaruhi oleh beberapa faktor, diantaranya masa kerja dan sistem pengembangan karir.

Sebagian besar responden memiliki masa kerja lebih dari 10 tahun. Masa kerja tersebut terbilang cukup lama sehingga tanpa disadari muncul stress karena rasa bosan terhadap pekerjaan monoton sebagai petugas pengumpul tol yang bekerja dalam lingkungan kerja terbatas di mana berada di dalam gardu tol. Sistem pengembangan karir bagi sebagian besar responden juga dirasakan sulit untuk dilakukan, sehingga mau tidak mau mereka menerima jabatan dan pekerjaan yang ada saat ini sampai berakhirnya masa kerja mereka.

Bila dibandingkan antar shift kerja, frekuensi responden dengan stress kerja ringan mengalami penurunan, sedangkan responden dengan stress kerja sedang mengalami peningkatan.

Hal tersebut dikarenakan pada saat pagi hari seseorang akan memiliki pola kerja normal di mana pagi hari digunakan untuk bekerja sedangkan pada saat sore dan malam dapat digunakan untuk beristirahat dan berkumpul dengan keluarga serta bersosialisasi dengan masyarakat. Pada pagi hari tubuh akan lebih fresh dan bersemangat dalam melakukan pekerjaan.

Pada saat sore dan malam hari seseorang sudah akan mengalami penurunan kemampuan konsentrasi, mulai merasakan kelelahan, kejenuhan yang menyebabkan tingkat stress kerja lebih tinggi dibandingkan pada saat pagi hari.
Menurut Grandjean (1988) manusia mempunyai fluktuasi dari berbagai macam fungsi tubuh selama 24 jam atau yang disebut dengan circadian rhythem yaitu jam biologis manusia normal.

Fungsi tubuh normal manusia dikelompokkan ke dalam dua fase, yaitu fase trophotropic dan fase ergotrophic. Fase trophotropic terjadi pada malam hari yaitu fase dimana tubuh melakukan pembaharuan cadangan energi atau penguatan kembali, sedangkan fase ergotrophic terjadi pada siang hari yaitu fase di mana semua organ dan fungsi tubuh siap untuk melakukan suatu tindakan.

Sistem shift kerja dapat bervariasi pada setiap organisasi maupun perusahaan. Hal tersebut tergantung dari pihak manajemen mengelola shift kerja apakah memperhatikan faktor sosial, psikologis, ekonomi, prasarana kerja dan pelayanan kesejahteraan tenaga kerja sebagai upaya untuk tenaga kerja dapat menyesuaikan diri terhadap shift kerja.

Sistem shift kerja yang diterapkan oleh PT. (X), Surabaya termasuk dalam sistem rotasi, di mana tenaga kerja tidak bekerja secara terus-menerus pada shift yang tetap atau sama. Sistem rotasi dianjurkan oleh pakar modern karena mempertimbangkan faktor sosial dan psikologis untuk industri yang bergerak pada bagian manufaktur dan kontinyu (Pulat dalam Ramayuli, 2004).

Jadwal shift kerja di PT. (X), Surabaya diatur dengan sistem 3-1-4-2 di mana 3 hari kerja dengan 1 hari libur, dan 4 hari kerja dengan 2 hari libur, begitu seterusnya untuk pola perulangannya.

Sistem rotasi shift kerja tersebut dapat dikatakan memiliki jarak pergantian yang relatif singkat, dan setelah melaksanakan shift kerja sore dan malam terdapat jadwal libur 1-2 hari.

Grandjean (1988), menyebutkan bahwa dalam pengaturan shift kerja perlu memperhatikan persyaratan di mana harus memberikan waktu istirahat atau libur selama 24 jam penuh setelah bekerja malam bahkan menyarankannya untuk memberikan waktu libur $2 \times 24$ jam penuh dengan alasan agar kehilangan waktu tidur sedapat mungkin dikurangi dan harus ada waktu yang cukup bagi kehidupan keluarga dan kontak sosial.

Eastman Kodak Company (1986), dibutuhkan waktu antara 1-2 hari untuk dapat menyesuaikan kembali ritme circadian individu dengan lingkungan alamiah di sekitarnya.

Manajemen shift kerja sudah dilakukan dengan baik oleh PT. (X), Surabaya dengan memperhatikan 
beberapa hal yang sesuai untuk manajemen shift kerja sesuai dengan Tayyari dan Smith (1997), yaitu (1) Mengurangi jumlah karyawan saat shift malam yang diperlukan agar jumlah hari kerja pekerja shift malam dapat berkurang, dalam hal ini pada saat shift III (malam) mengurangi jumlah gardu tol yang aktif sudah dilakukan, (2) Setelah bekerja saat shift siang ataupun malam seharusnya diikuti dengan paling sedikit 24 jam atau satu hari libur dan untuk tiap bekerja saat shift malam dengan memberikan paling sedikit $2 \times 24$ jam atau dua hari libur sehingga kebiasaan tidur pekerja dapat diatur, hal tersebut sudah dilakukan dengan adanya sistem shift kerja 3-1-4-2 yaitu 3 hari kerja 1 hari libur dan 4 hari kerja 2 hari libur, serta (3) Selama bekerja saat shift malam pemberian musik yang tidak monoton sangat berguna bagi pekerja, dalam hal ini telah disediakan oleh pihak PT. (X), Surabaya yang dapat kita temui ketika melintasi gerbang tol pada saat malam hari akan terdengar keras suara musik dari dalam gardu tol yang berfungsi untuk mengurangi kebosanan.

PT. (X), Surabaya juga menyediakan jam istirahat pada setiap shift kerja petugas pengumpul tol yaitu satu jam. Namun untuk waktu istirahat di setiap shift kerja berbeda tergantung dari kondisi arus lalu lintas kendaraan roda empat dan berat yang menggunakan jalan tol. Waktu istirahat petugas pengumpul tol telah ditentukan tiap gerbang tol. Pada setiap gerbang tol penentuan waktu istirahat berbeda tergantung dari padatnya arus lalu lintas yang ada di setiap gerbang tol. Dengan demikian pada situasi yang memungkinkan maka barulah memiliki waktu istirahat yang panjang. Namun untuk jam istirahat sama untuk setiap shift-nya diberikan waktu istirahat satu jam.

Menurut Suma'mur (1994), menyatakan bahwa istirahat yang demikian merupakan istirahat dengan proses kerja di mana istirahat tergantung dari bekerjanya mesin peralatan atau prosedur kerja.

\section{SIMPULAN}

Berdasarkan hasil penelitian tingkat stress kerja antar shift kerja, pada saat shift I (pagi) terdapat 15 responden $(41,7 \%)$ mengalami stress kerja ringan dan 21 responden (58,3\%) mengalami stress kerja sedang. Pada saat shift II (sore) terdapat 12 responden $(33,3 \%)$ mengalami stress kerja ringan dan 24 responden $(66,7 \%)$ mengalami stress kerja sedang, sedangkan pada saat shift III (malam) sebanyak 9 responden (25\%) mengalami stress kerja ringan dan 27 responden (75\%) mengalami stress kerja sedang.

Dari hasil penelitian yang telah dilakukan dapat disimpulkan pada ketiga shift kerja responden mengalami stress kerja ringan dan sedang. Frekuensi terbesar responden mengalami stress kerja sedang pada ketiga shift kerja.

Adapun saran yang diberikan kepada pihak perusahaan adalah (1) Menganalisis atau mengkaji ulang sistem pengembangan karir atau promosi jabatan sehingga mudah dilaksanakan oleh karyawan, dan (2) Mempertahankan dan meningkatkan program pelatihan keterampilan dan kegiatan training kepada karyawan baru sehingga mengurangi timbulnya stress kerja.

Sedangkan saran yang dapat diberikan kepada responden atau karyawan adalah (1) Melakukan olahraga secara rutin misalnya sekedar pemanasan peregangan otot. Beberapa studi menunjukkan bahwa olahraga teratur dapat memberikan dampak yang cukup baik untuk kesehatan tubuh karena tubuh yang sehat dapat membuat pekerja melawan stress, dan (2) Memanfaatkan waktu istirahat atau libur dengan sebaik-baiknya agar tubuh dapat beristirahat, stamina dan irama sirkadian tubuh tetap terjaga. Misalnya dengan berbaring sejenak, duduk dengan menyandarkan punggung agar tubuh sedikit lebih rileks, ataupun tidur lebih awal agar saat bekerja tidak mengalami gangguan tidur.

\section{DAFTAR PUSTAKA}

Andarika, R. 2004. Burnout Pada Perawat Putri RS St. Elizabeth Semarang Ditinjau dari Dukungan Sosial. Jurnal Psyche . Vol. 1. No. 1, 1-8.

Anoraga, P. 1992. Psikologi Kepemimpinan. Jakarta: Rineka Cipta.

Dinas Infokom Jatim. 2009. Volume Lalin Meningkat, Jasa Marga Maksimalkan CCTV. http://www. jatimprov.go.id. (sitasi 19 Februari 2015)

Eastman Kodak Company, Ergonomics Group. 1986. "Ergonomic Design for People at Work", (Vol.2). New York: Van Nostrand Reinhold.

Friedman dan Ulmer. 1984. Treating Type a Behavior - And Your Heart. New York: Knopf.

Friedman dan Roseman. 1974. Type A Behavior And Your Heart. New York: Knopf.

Grandjean, E. 1988. Fitting The Task to The Man, a Text book of Occupational Ergonomics, $4^{\text {th }}$ edition. London: Taylor and Francis Ltd. 
Gunarsa, S D. 2008. Psikologi Perawatan. Jakarta: Gunung Mulia.

Hurlock, E. 2001. Psikologi Perkembangan Edisi Kelima. Jakarta: Erlangga.

Jasamarga. 2015. Produk dan Layanan SurabayaGempol. http://www.jasamarga.com/produk dan_layanan/surabaya-gempol/ (sitasi $10 \mathrm{Juli}$ 2015).

Martina, A. 2012. Gambaran Tingkat Stres Kerja Perawat di Ruang Rawat Inap Rumah Sakit Paru Dr. Moehammad Goenawan Partowidigdo Cisarua Bogor (RSPG). Skripsi. Depok: Universitas Indonesia.

Mc. Cormick, E.J and D.R. Ilgen. 1985. IndustrialOrganizational Psychology. $8^{\text {th }}$ ed. New Jersey: Prentice-Hall, Inc.

Munandar, A.S. 2001. Psikologi Industri dan Organisasi. Jakarta: Penerbit Universitas Indonesia (UI-PRESS).

National Institute of Occupational Safety and Health (NIOSH). 2000. Stess At Work. NIOSH Publication No. 99-101. http://www.cdc.gov/ Niosh/stresswk.html (sitasi 30 Juni 2015).

Nazir, Moh. 1998. Metode Penelitian. Jakarta: Ghalia Indonesia.

Parasuraman., Greenhaus., Granrose, J.H. 1992. Role Stressors, Social Support and Well-being Among Two-Career Couples. Journal of Organizational Behavior. Vol. 13, No. 4, 339-356.

Ramayuli, S. 2004. Hubungan Faktor Individu dan Shift Kerja dengan Produktivitas Tenaga Kerja Wanita pada Bagian Pengepakan di PT. INDOFOOD Sukses Makmur Tbk. Cabang Medan Tahun 2004. Skripsi. Medan: Universitas Sumatra Utara.

Revalicha, N.S. dan Sami'an. 2013. Perbedaan Stres Kerja Ditinjau dari Shift Kerja pada
Perawat di RSUD Dr. Soetomo Surabaya. Jurnal Psikologi Industri dan Organisasi. Vol. 2 No. 01, 163-171.

Robbins, S.P. 2006. Perilaku Organisasi: Konsep, Kontroversi, Aplikasi. Jakarta: PT. Prenhallindo.

Santrock, J.W. 2003. Adolescene (6 ${ }^{\text {th }}$ edition). http:// books.google.co.id.books?id=Z3LWSxbTv4C \&printsec $=$ frontcover $\# \mathrm{v}=$ onepage $\& \mathrm{q} \& \mathrm{f}=$ false. (sitasi 18 November 2014)

Saragih, E. 2010. Manajemen Stres Di Tempat Kerja. http://ppm-manajemen.ac.id/manajemenstres-di-tempat-kerja/. (sitasi 18 November 2014)

Siboro, S.T. 2008. Hubungan Kondisi Kerja dan Karakteristik Individual dengan Stress Kerja pada Pegawai Lembaga Permasyarakatan Klas II B Lubuk Pakam 2008, 2009. Skripsi. Medan: USU Repository.

Suma'mur, P.K. 1994. Keselamatan Kerja dan Pencegahan Kecelakaan. Jakarta: CV. Haji Masagung.

Tayyari, F., dan Smith J. L. 1997. Occupational Ergonomics: Principles and Applications. London: Chapman \& Hall.

Walker, J. 2002. Teens in Distress Series Adolescent Stress and Depression, Minnesota University. Available from: http://www.extension.umn.edu/ distribution/youthdevelopment/DA3083.html (Accesed 4 March 2010)

Wildani, A.A. 2012. Gambaran Tingkat Stres Kerja Pada Pegawai Dinas Kesehatan Kota Depok. Skripsi. Depok: Universitas Indonesia.

Winarsunu, T. 2008. Psikologi Keselamatan Kerja. Malang: UMM Press.

Zahra, A.A. 2015. Analisis Tingkat Stress Kerja Antar Shift Kerja Pada Penjaga Pintu Tol di PT. Jasa Marga (Persero) Cabang Surabaya-Gempol. Skripsi. Surabaya: Universitas Airlangga. 